\section{MP-121 当院における尿中分離菌の検討一第 2 報一}

\section{セコメディック病院泌尿器科1", 東京大学医学部泌尿器 科 ${ }^{2)}$}

寺田 洋子 ${ }^{12}$, 野田 泰照 ${ }^{11}$, 徳田 拓 ${ }^{12}$, 北村 唯-..2)

【目的】当院に扮ける最近の 3 年間の尿中分離菌種亡抗菌 薬感受性の動向を検索する。【方法】 laboratory based surveillance を行い、当院の尿由来菌の分離状況と薬剂 感受性を検討する。【対象】 2003 年〜2005 年の 3 年間の 当院検査室の細菌検査結果票のうちの尿培盖検查結果票 より尿中分離菌を集計し、抗菌薬感受性を検討した。主 要菌腫に打ける抗菌薬感受性を検討した。男女別、自然 尿・カテーテル尿の分類が可能で 2003 年 217 株、2004 年 386 株の集計の結果については第 70 回日本泌尿器科 学会東部総会で一部発表した。今回、更に 2005 年度の集 計を加えて検討したので報告する。【結果】当院で最も 高頻度で分離された菌は、E.Coli で各抗菌薬に対して良 好な感受性を示した。【考案】尿培養検査結果によるlaboratory based surveillance は尿路感染症の菌種の推定の 一助となり, 抗菌薬の選択上でも有用となり得ると考え られた。
前立腺生検時のレボフロキサシン単回 投与による感染阻止効果の検討

\footnotetext{
埼玉医科大学総合医療センター泌尿器科

大野 玲奈. 吉永 敦史, 吉田 宗一郎, 石井 信行,

寺尾 俊哉, 渡邊 徹, 林 哲夫, 山田 拓己 【目的】当科では 2003 年 6 月より、前立腺生検前にレボフロキ サシンの単回投与を行い経会陰的 8 ケ所の生検を行っている。 第 92 回本総会で報告したが、今回さらに症例を追加して報告 する。【対象と方法】 2002 年 9 月から 2005 年 7 月までに易感 染性やキノロン系薬郕に対するアレルギーの既往、膿尿を認め ない、男性患者 299 名において、2002 年 9 月から 2003 年 5 月までの第 1 群はセフェム系抗菌剂 4-7 日間投与、2003 年 6 月から 2005 年 7 月までの第 2 群は前立腺生検施行 1 - 2 時間 前にレボフロキサシン単回投与とした。各群での生検後尿路感 染症の有無について比較検討した。前立腺生検翌日に（1）38 ${ }^{\circ} \mathrm{C}$ 以上の発熱及び尿意促拍、頻尿、恥骨上の圧痛などの自覚症 状または (2) 尿沈椬で白血球数 10 個/hpf 以上の膿尿またはグ ラム染色で微生物が見られる、の 2 項目について評価し、少な くとも(2) を認めるものを尿路感染ありと判定した。【結果】 レボフロキサシン内服と関連すると思われる副作用症状を認 める症例はなかった。発熱、尿意促拍などの症状を認めた症例 はなく、膿尿が出現したものは第 1 群では 1 名 $(1.7 \%)$ 第 2 群で 4 名 (2.0\%) 4 名であった。【結論】今後さらに症例数を 重ねる予定であるが、これまでの結果では、前立腺生検前のレ ボフロキサシン単回投与は、感染阻止法として有効といえる。
}

\section{MP-123 前立腺全摘除術の周術期感染予防にお ける抗生剤 1 日投与法の検討}

\section{倉敷中央病院泌尿器科(1), 桂病院泌尿器科 ${ }^{2)}$}

寺井 章人 ${ }^{1}$, 市岡 健太郎 ${ }^{22}$, 公平 直樹 ${ }^{1)}$,上田 修史 ${ }^{12}$, 宇都宮 紀明1), 青山 輝義1), 國枝 太史 ${ }^{11}$, 井上 幸治 ${ }^{11}$ 【目的】前立腺全摘除術は準無菌手術とされるが、周術期感染予防 のための抗生剂静脈内投与の適正期間に関する検討は少ない。今 回われわれは手術当日のみの抗生剂静脈内投与の術後感染予防 効果につき検討した。【方法】当院でクリニカルパスを用いて 2004 年 $1 \sim 12$ 月に恥骨後式前立腺全摘除術を施行した 50 例 (cefotiam 4 日間投与）と 2004 年 12 月〜2005年 7 月に手術した 56 例 (cefotiam 1 日投与)を対象とし周術期感染について検討した。 抗生剂は皮膚切開 30 分前に点滴静注し、以後は病棟㷌室後に投 与した。皮膚切開は 6 9cmであった。【成績】両群の患者背景 (年齢、合併症、BMI、臨床病期)には有意差を認めなかった。 4 日投与群、 1 日投与群の平均手術時間は 260 分、253 分、平均出血 量は $1737 \mathrm{~g} 、 1479 \mathrm{~g}$ 、同種血輸血は $12 \% 、 5 \%$ で有意差を認めな かった。閉創法は 4 日投与群では $92 \%$ がナイロン糸結節縫合、 1 日投与群では $98 \%$ が真皮埋没縫合+ダーマボンド塗布であっ た。手術部位感染は 4 日投与群では認められなかったが、1 日投 与群では 1 例 $(1.8 \%)$ で緑膿菌による表在性創感染が認められ た。遠隔感染は雨群ともに認めなかった。また 1 日投与群の 1 例で $38^{\circ} \mathrm{C}$ 超の不明熱が 4 日間持続したため予定外の抗生唷投与 を行った。【結諭】前立腺全摘除術後の周術期感染予防目的には 手術当日のみの抗生剤静脈内投与で十分であると考えられる。

\section{MP-124 男性淋菌性尿道炎の検討}

\author{
高知医療センター泌尿器科 \\ 安東 栄一, 横田 雅生, 入口 弘英, 小野 憲昭, \\ 那須 良次
}

【目的】近年男性淋菌性尿道炎は増加傾向にあり、フルオ ロキノロン耐性など淋菌の薬剂耐性化が大きな問題と なっている。今回当科における淋菌性尿道炎の傾向につ いて検討した。

【対象・方法】対象は 2001 年 1 月以降、当科を受診した 男性淋菌性尿道炎のうち、菌株の保存が可能であった 50 例を対象とした。患者背景 (年齢、感染源)、治療薬、臨 床効果、各種抗菌薬に対する薬剤感受性について検討し た。

【結果】年齢は 17 歳から 48 歳 (中央值 : 27 歳).゙あった。 感染源はコマーシャルセックスワーカー $56 \%$ 、ガールフ レンド $22 \%$ 、pick up 14\%、不明 $8 \%$ であった。クラミジ アとの合併頻度は $30 \%$ であった。 50 例中 36 例で初回治 療の效果判定が可能であった。36 例中 SPCM 投与例は 30 例で、すべて治療効果を認めた。初回治療失敗は 3 例でCVA/AMPC、CPDX-PR、LVFXが用いられてい た。各種薬剤に対する耐性率（NCCLS の判定基準で intermediate 以）は PCG $83.7 \%$ 、CFIX $5.4 \%$ 、CTRX 8.1\%、CDZM 2.7\%、MINO 60\%、OFLX 75\% であった。 【結論】男性淋菌性尿道炎に対して SPCM 単回投与は有 効であった。 